\title{
HUBUNGAN KONSUMSI SENG SEBAGAI KOFAKTOR MAKANAN TRADISIONAL MINANGKABAU DENGAN NEUTROFIL ELASTASE DALAM CAIRAN SULKUS GINGIVA PADA PENYAKIT PERIODONTAL
}

\author{
(RELATION OF ZINC CONSUMPTION AS COFACTOR IN MINANGKABAU \\ TRADITIONAL FOOD WITH NEUTROPHIL ELASTASE LEVEL IN \\ GINGIVAL CREVICULAR FLUID IN PERIODONTAL DISEASE)
}

\author{
Nila Kasuma \\ Departemen Periodonsia \\ Fakultas Kedokteran Gigi, Universitas Andalas \\ Jl. Perintis Kemerdekaan No.77, Padang-Sumatra Barat 25121
}

\begin{abstract}
This study involved 66 people consist of 22 healthy samples, mild gingivitis, and periodontitis samples. Enzyme levels were tested using ELISA technique. This is a cross-sectional study that compared the levels of enzyme neutrophil elastase in healthy samples, mild gingivitis and mild periodontitis in each group. Data was analyzed using univariate way to describe each variable, to see normal distribution ( $p>0.05$ ) Kolmogorov Smirnof Test was used. The levels of neutrophil elastase was the highest in mild periodontitis with an average of $9.42 \pm 1.06 \mathrm{ng} / \mathrm{dl}$. Levels of zinc consumption is highest in healthy patients with an average of $6.39 \pm 1.26 \mathrm{mg}$. Pearson Correlation Test was used to prove the relationship between the concentration of neutrophil elastase with zinc consumption in Minangkabau traditional food. The result showed that there was a significant relationship $(p=0,000)$ between neutrophil elastase concentration with zinc consumption levels in Minangkabau foods. The relationship between neutrophil elastase and zinc showed a strong correlation negative pathway $(r=-0,784)$. In conclusion, there was a relationship between neutrophil elastase with zinc as a cofactor in Minangkabau traditional food in periodontal disease.
\end{abstract}

Key words: periodontitis, neutrophil elastase, zinc

\begin{abstract}
Abstrak
Penelitian ini melibatkan 66 orang sampel terdiri atas 22 orang sehat, 22 orang mengalami gingivitis ringan dan 22 orang mengalami periodontitis awal. Kadar enzim yang diteliti diuji dengan menggunakan teknik ELISA. Rancangan penelitian adalah cross sectional yang membandingkan kadar enzim netrofil elastase pada sampel sehat, gingivitis ringan dan periodontitis awal. Untuk melihat distribusi normal $(p>0,05)$ dilakukan tes Kolmogorov Smirnof. Terdapat kadar neutrofil elastase yang paling tinggi pada periodontitis ringan dengan rata-rata 9,42 $\pm 1,06 \mathrm{ng} / \mathrm{dl}$. Kadar konsumsi seng yang paling tinggi adalah pada pasien sehat dengan rata-rata 6,39 $\pm 1,26 \mathrm{mg}$. Tes Pearson Correlation digunakan untuk membuktikan hubungan antara konsentrasi neutrofil elastase dengan konsumsi seng pada makanan tradisional Minangkabau. Hasil penelitian menunjukkan korelasi yang signifikan $(p=0,000)$ antara konsentrasi neutrofil elastase dengan kadar konsumsi seng pada makanan tradisional Minangkabau. Hubungan antara neutrofil elastase dan seng menunjukkan korelasi yang kuat berarah negatif $(\mathrm{r}=-0,784)$. Sebagai kesimpulan, terdapat hubungan konsumsi seng sebagai kofaktor makanan tradisional Minangkabau dengan neutrofil elastase dalam gingival crevicular fluid penyakit periodontal.
\end{abstract}

Kata kunci: periodontitis, neutrofil elastase, seng

\section{PENDAHULUAN}

Mikronutrien seperti seng berperan dalam re- generasi, mengontrol stress oksidatif, dan respons imun yang adekuat. Oleh karena itu elemen ini sangat esensial dalam menjaga kesehatan tubuh. 
Kadar seng merupakan faktor yang berkontribusi dalam kondisi inflamasi, salah satunya penyakit periodontal. ${ }^{1}$

Penyakit periodontal berkembang dari tahap early lession pada marginal gingivitis menjadi periodontitis yang sangat destruktif, yang ditandai dengan kerusakan jaringan pendukung, epitelium, attachment loss (kehilangan perlekatan), kerusakan tulang dan mobiliti gigi bahkan kehilangan gigi apabila tidak segera dirawat. ${ }^{2}$ Penyakit periodontal terjadi karena interaksi antigen bakteri dengan jaringan host sehingga mengaktivasi neutrofil, produksi antibodi, dan resorpsi tulang. ${ }^{3}$

Angka kejadian penyakit periodontal merupakan penyakit kedua terbanyak di rongga mulut karena terapi inisial pada gingivitis yaitu skeling dan root planing ternyata tidak dapat menyingkirkan penyakit periodontal secara tuntas. Di bidang kedokteran gigi perkembangan diagnostik dan terapi terus dilakukan, salah satunya dengan pengambilan media biologis yang dipilih yaitu air liur, serum, plak subgingiva, biopsi jaringan, dan cairan sulkus gingiva (gingival crevicular fluid) untuk mengukur tingkat inflamasi agar dapat memilih terapi yang tepat. Gingival Crevicular Fluid (GCF) adalah eksudat inflamasi yang disekresikan gingiva pada sulkus gingiva tepat di pertemuan antara gingiva dan gigi. Komposisi GCF adalah subtansi host, dan bakteri supragingival dan subgingival. Subtansi host terdiri atas molekul yang berasal dari darah dan jaringan periodontal. Sel inflamatori dan imun menginfiltrasi ke jaringan periodontal, marker inflamasi yaitu enzim sitokin, interleukin, dan produk penghancuran jaringan juga ditemukan di GCF. ${ }^{4}$

Konsentrasi GCF pada keadaan normal adalah rendah, namun pada keadaan inflamasi terjadi peningkatan. Pasien dengan penyakit periodontal aktif menunjukkan konsentrasi GCF yang lebih tinggi dibandingkan pasien yang sehat. ${ }^{5}$ Gingival crevicular fluid (GCF) adalah metode analisis periodontitis yang non invasif, sebagai indikator dan marker kerusakan jaringan penghubung dan tulang yang berguna dalam menentukan keparahan penyakit periodontal. $^{6}$

Pada periodontitis, level sitokin dan aktivitas enzim yang berasal dari host di GCF digunakan untuk mendeteksi inflamasi dan respon host terhadap periodontopatogen yaitu P.gingivalis dan bakteri lainnya. Respons host yang efektif dimediasi oleh neutrofil, ditandai dengan influx neutrofil ke sulkus gingiva. Salah satu mekanisme antimikrobial neutrofil adalah dengan melepaskan enzim yaitu Neutrofil Elastase (NE) yang dapat menghancurkan bakteri periodontopatogen. ${ }^{7}$

Neutrofil elastase adalah salah satu enzim pro- teolitik yang terdapat di granula primer PMN (azurophilic), dilepaskan pada saat aktivasi PMN dan dapat mendegradasi protein matriks ekstraseluler jaringan penghubung. ${ }^{8}$ Neutrophyl elastase bekerja pada kolagen dengan mendegradasi serat-serat kolagen dan elastin. Elastin yang berfungsi untuk memberikan kemampuan jaringan untuk meregang dan mendukung kesehatan sel. ${ }^{9,10}$ Pemeriksaan kadar NE berguna pada inflamasi tahap awal, karena neutrofil merupakan sel mayor yang bermigrasi dari sirkulasi darah ketempat inflamasi ${ }^{11}$.Konsentrasi dan aktivitas NE di GCF dapat digunakan untuk mengidentifikasi perbedaan aktivitas penyakit antar pasien periodontitis dan mengukur inflamasi gingiva. ${ }^{8}$

Seng adalah salah satu kofaktor neutrofil elastase (NE). ${ }^{11}$ Seng tersebar di dalam semua sel di tubuh manusia, dan merupakan ion logam kedua ter-banyak setelah zat besi. Seng ditemukan di dalam komponen seluler dan memiliki peran fisiologis yaitu katalisis, struktural dan fungsi regulasi. ${ }^{12}$

Seng adalah nutrisi esensial yang dibutuhkan manusia untuk fungsi fisiologis termasuk imunitas, antioksidan, pertumbuhan, dan reproduksi. Defisiensi seng mempengaruhi sistem imun .Studi yang dilakukan oleh Orbak et al. ${ }^{13}$ pada 14 ekor tikus Sprague-Dwaley yang menghentikan laktasi pada hari ke 24 setelah lahir. Grup pertama diberikan diet dengan defisiensi seng, grup kedua diberikan diet yang kaya akan seng. Keadaan jaringan periodontal meliputi indeks gingiva (Löe-Silness), indeks plak (Silness-Löe), dan kedalaman poket dievaluasi pada minggu keempat. Kemudian sampel darah yang diambil untuk mengukur kadar seng. Skor indeks plak dan indeks gingiva lebih rendah pada grup yang diberikan diet yang kaya akan seng.

Defisiensi seng dapat mempengaruhi kapasitas regeneratif, imunitas alami dan dapatan dengan menurunkan aktivitas fagositosis makrofag dan neutrofil, aktivitas natural killer cell, respons antibodi, antioksidan, dan jumlah sel T sitotoksik. ${ }^{14}$

Kandungan seng yang dikonsumsi dalam makanan diukur dengan Food Frequency Questioner. Food Frequency Questionnaires (FFQs) didesain untuk mengkaji kebiasaan diet dengan menanyakan frekuensi makanan dan minuman yang dikonsumsi dalam periode tertentu. Metode ini sering digunakan sebagai metode mengkaji kebiasaan diet pada studi epidemiologis dan riset tentang nutrisi. FFQ mudah dilakukan, tidak membutuhkan banyak biaya, dan metode ukur intake makanan yang cepat dan sederhana. ${ }^{15}$

Tujuan penelitian untuk mengetahui hubungan konsumsi seng sebagai kofaktor yang diukur dengan Food Frequency Questioner pada 220 makanan tradisional Minangkabau dengan kadar neutrofil 
elastase dalam gingival crevicular fluid pada penyakit periodontal.

\section{BAHAN DAN METODE}

Desain penelitian adalah Cross Sectional Comparative Study. Sampel penelitian adalah pasien berusia 17-30 tahun yang berkunjung ke Poliklinik Gigi Rumah Sakit Umum Daerah kota Padang, Sumatera Barat, Indonesia, bersuku Minangkabau yang mengkonsumsi makanan Minangkabau setiap hari.

Terdapat tiga kelompok sampel. Kelompok pertama (kelompok studi) terdiri atas 20 orang pasien sehat. Kelompok kedua pasien dengan gingivitis ringan yaitu 20 orang, dan kelompok ketiga 20 orang pasien periodontitis ringan.

Pengambilan sampel dilakukan dengan teknik consecutive sampling sesuai dengan kriteria inklusi dan eksklusi. Kriteria inklusi yaitu pasien bersedia dan menandatangani informed consent sebagai sampel dalam penelitian ini. Kriteria eksklusi yaitu tidak mengkonsumsi antibiotik dan anti inflamasi selama 3 bulan terakhir, merokok, hamil, mestruasi, memiliki kelainan sistemik seperti Diabetes melitus, memiliki riwayat perawatan periodontal selama 3 bulan terakhir. Semua subjek telah membaca dan menandatangani informed consent yang telah disetujui oleh subjek dan komisi etik penelitian.

Pemeriksaan pertama jaringan periodontal menggunakan Periodontal Disease Index menurut Russel. Pemeriksaan gusi atau jaringan periodontal menggunakan instrumen probe periodontal. Alat ini digunakan untuk mengukur kedalaman saku gusi. Kedalaman normal saku gusi berkisar 0-3 mm. Skor Periodontal Disease Index adalah:

$$
\begin{aligned}
& 0=\text { gingiva sehat } \\
& 1=\text { gingivitis ringan } \\
& 2=\text { gingivitis berat } \\
& 4=\text { periodontitis ringan }
\end{aligned}
$$

Kriteria pengukuran 6 regio gigi $(16,21,24,36$, 41 dan 44) mewakili indeks penyakit periodontal menurut Russel, apabila salah satu dari 6 regio gigi hilang dapat diganti dengan gigi sebelahnya.

Gingiva Crevicular Fluid dikumpulkan menggunakan absorbent paper dilakukan pada pagi hari pukul 08.00 WIB sesuai dengan Cicardian Periodicity. Area pengambilan GCF dibersihkan dari plak. Untuk menyamakan kondisi dan meminimalisasi keterlibatan bakteri oral pasien dinstruksikan berkumur menggunakan larutan $2 \%$ chlorhexidin. Subjek diinstruksikan untuk tidak makan dan minum 1 jam sebelum pengumpulan GCF. Kemudian bibir diretraksi dan diisolasi dengan menggunakan coton roll. Absorbent paper dimasukkan dengan menggunakan teknik superfisial intracrevicular dan dibiarkan selama 3 menit. Absorbent paper diambil, dan diletakkan dalan tabung eppendorf yang telah diisi oleh Phosphate Buffer Solution. Spesimen diberi label. Sampel yang diambil akan dianalisis menggunakan ELISA dan disimpan pada suhu $20^{\circ} \mathrm{C}$.

Analisis level NE dilakukan di Laboratorium Biomedik Fakultas Kedokteran Universitas Andalas, Sumatera Barat, Indonesia. Sampel yang diambil dianalisa menggunakan ELISA. Reagen yang digunakan Elastase, Human, Kit, HK319-02, Product assays, quantity $2 \times 96$ det, standard range 0.4-25 $\mathrm{ng} / \mathrm{ml}$, detection $0.4 \mathrm{ng} / \mathrm{ml}$, working volume 100 $\mu \mathrm{l} / \mathrm{well}$.

Setiap subjek diinstruksikan untuk mengisi Food Frequency Questioner yang meliputi 220 makanan Minangkabau yang diolah dengan digulai, digoreng, direbus, ditumis, dan dipanggang. Subjek juga diinstruksikan untuk mengingat frekuensi mengonsumsi makanan tersebut dalam satu minggu terakhir, porsi dan ukuran dalam unit pengukuran standar.

Data dianalisis menggunakan SPSS 17. Jumlah neutrofil elastase ditabulasi dan diverifikasi secara statistik menggunakan Kolmogorov Smirnof Test untuk menguji distribusi normal dari data, hubungan antara neutrofil elastase dan Periodontal Disease Index digunakan uji ANOVA. Untuk melihat perbedaan kadar NE antar grup diuji dengan Post- Hoc Bonferroni. Pearson Correlation Test digunakan untuk melihat hubungan konsumsi seng dengan NE.

\section{HASIL}

Subjek penelitian terdiri atas laki-laki $35 \%$ berusia rata-rata $21,15 \pm 31,18$ dan $65 \%$ perempuan berusia rata-rata 23,39 $\pm 4,39$. Jumlah sampel adalah 22 orang subjek yang sehat, 22 orang pasien gingivitis ringan, dan 22 orang pasien periodontitis ringan.

Tabel 1. Rata-rata umur subyek berdasarkan jenis kelamin

\begin{tabular}{lcccc}
\hline Umur & Jenis kelamin & $\mathrm{n}$ & $\%$ & Rata-rata \\
\hline \multirow{2}{*}{$17-30$ tahun } & Laki-laki & 17 & 35 & $21,15 \pm 31,8$ \\
& Perempuan & 49 & 65 & $23,39 \pm 4,39$ \\
\hline
\end{tabular}

Terdapat perbedaan rata-rata kadar Neutrofil Elastase berdasarkan kelompok PDI, yang tertinggi terdapat pada Periodontitis ringan dengan rata-rata $=$ 9,42 $\pm 1,06 \mathrm{ng} / \mathrm{dl}$. (Tabel 2)

Tabel 2 menunjukkan penderita gingivitis ringan berpeluang mengalami peningkatan kadar NE sebanyak 2,5 kali lipat dibanding kondisi sehat, sedangkan pada kondisi peridontitis ringan naik 3,7 kali lipat dibanding kondisi sehat. 
Untuk melihat perbedaan antar kelompok maka dilanjutkan dengan uji Post-hoc Bonferroni. Terdapat perbedaan rata-rata Neutrofil Elastase yang signifikan antara kelompok sehat dengan gingivitis ringan, kelompok sehat dengan periodontitis ringan, dan juga antara kelompok gingivitis ringan dengan periodontitis ringan $(\mathrm{p}<0,05)$. (Tabel 3$)$

Tabel 2. Perbedaan rata-rata kadar neutofil elastase (ng/dl) dalam gingival crevicular fluid dengan penyakit periodontal Berdasarkan PDI

\begin{tabular}{llccc}
\hline Jenis enzim & PDI & n & Rata-rata & $\mathrm{p}$ \\
\hline \multirow{4}{*}{$\begin{array}{l}\text { Neutrofil } \\
\text { elastase }\end{array}$} & Sehat & 22 & $2,65 \pm 1,28$ & 0,00 \\
& Gingivitis & 22 & $6,27 \pm 1,13$ & \\
& ringan & & & \\
& Periodontitis & 22 & $9,42 \pm 106$ & \\
& ringan & 66 & $6,11 \pm 3,47$ & \\
\hline
\end{tabular}

Tabel 3. Hasil uji Post-Hoc Bonferroni kadar enzim neutrofil elastase antar kelompok PDI

\begin{tabular}{lccc}
\hline \multicolumn{3}{c}{ Kadar NE } \\
\hline PDI & Sehat & $\begin{array}{c}\text { Gingivitis } \\
\text { ringan }\end{array}$ & $\begin{array}{c}\text { Periodontitis } \\
\text { ringan }\end{array}$ \\
\hline $\begin{array}{l}\text { Sehat } \\
\begin{array}{l}\text { Gingivitis } \\
\text { ringan }\end{array}\end{array}$ & - & 0,000 & 0,000 \\
$\begin{array}{l}\text { Periodontitis } \\
\text { ringan }\end{array}$ & 0,000 & - & 0,000 \\
\hline
\end{tabular}

Tabel 4. Perbedaan konsumsi seng (mg) diukur dengan Food Frequency Questioner pada 220 macam makanan Minangkabau berdasarkan PDI

\begin{tabular}{lllc}
\hline PDI & $\mathrm{n}$ & Rata-rata & $\mathrm{p}$ \\
\hline Sehat & 22 & $6,39 \pm 1,26$ & 0,00 \\
Gingivitis ringan & 22 & $4,51 \pm 0,34$ & \\
Periodontitis ringan & 22 & $2,18 \pm 0,21$ & \\
\hline Total & 66 & 4,36 & \\
\hline
\end{tabular}

Analisis statistik dengan Pearson correlation test menunjukkan koefisien korelasi (r) adalah -0,784 dengan significance level $\mathrm{p}=0,000$ antara kadar neutrophil elastase dengan konsumsi seng.

\section{PEMBAHASAN}

Hasil penelitian ini menunjukkan hubungan yang bermakna antara kadar konsumsi seng sebagai kofaktor yang diukur dengan Food Frequency Questioner terhadap 220 jenis makanan tradisional Minangkabau dengan kadar Neutrofil Elastase dalam Gingival Crevicular Fluid pada penyakit periodontal $(\mathrm{p}<0,05)$.

Pada 66 orang sampel terjadi peningkatan kadar neutrofil elastase pada lokasi inflamasi dibandingkan dengan subjek yang sehat. Ini mengindikasikan bahwa kadar neutrofil elastase pada GCF merupakan faktor resiko periodontitis. Rata-rata kadar seng yang dikonsumsi grup kontrol (sehat) adalah 6,39 \pm $1,26 \mathrm{mg}$ lebih banyak 1,41 kali dibandingkan kondisi gingivitis ringan dan 2,9 kali dibandingkan kondisi periodontitis ringan. Pasien gingivitis ringan mengkonsumsi seng rata-rata $4,51 \pm 0,34 \mathrm{mg}$. Pada kondisi periodontitis ringan rata-rata konsumsi seng adalah 2,18 $\pm 0,21 \mathrm{mg}$.

Berdasarkan analisis statistik dengan Pearson Correlation Test, hubungan antara konsumsi Seng sebagai kofaktor dengan kadar Neutrofil Elastase arah korelasi negatif dan kekuatan korelasi kuat $(\mathrm{r}=$ $-0,784$ ) dengan $p=0,000$, yang artinya semakin bertambah konsumsi Seng maka kadar NE rendah. Hal ini menunjukkan bahwa lokasi dengan kadar nutrofil elastase yang tinggi mengindikasikan resiko peningkatan alveolar bone loss dan attachment loss yang progresif dan sebaliknya, semakin rendah kadar NE maka semakin rendah potensi terjadinya kerusakan periodontal lebih lanjut. ${ }^{16}$

Penyakit periodontal merupakan infeksi dan kerusakan jaringan periodontal sebagai respon host terhadap inflamasi. ${ }^{17}$ Pada periodontitis terjadi ulserasi epitel sehingga menjadi jalan masuk bagi bakteri periodontopathogen. Oleh karena itu banyak sel imunokompeten yang direkrut ke lamina propria di sulcus epithelium. Neutrofil adalah sel yang dominan dan merupakan sel penghasil utama NE. ${ }^{18}$

Neutrofil Elastase (NE) adalah enzim hidrolitik yang berfungsi dalam degradasi material asing yang ditelan dalam proses fagositik. NE adalah protein serin dan mengandung rantai tunggal polipeptida dasar dari 218 residu asam amino yang disatukan oleh empat ikatan disulfide. NE juga memiliki dua rantai asparagines yang terikat dengan karbohidrat. Neutrofil Elastase juga dikenal sebagai ELA2 (elastase 2, neutrofil) merupakan asam amino protease yang sama seperti chymotrypsin yang memiliki substrat spesifik yang luas. ${ }^{11}$

Neutrofil Elastase merupakan grup enzim serine proteinase. Active site NE, yaitu Asparagin, Histidin dan Serin. Substrat NE adalah elastin, collagen tipe III, IV, VI, dan VIII, fibronectin, laminin I, Thrombospondin, proteoglican. ${ }^{9}$ Neutrofil Elastase disekresikan oleh neutrofil dan makrofag selama peradangan, menghancurkan bakteri dan jaringan gingiva, yang mempunyai kofaktor seng dan magnesium. ${ }^{11}$

Seng terlibat dalam metabolisme asam nukleat dan protein, proses diferensiasi dan replikasi. Seng berfungsi dalam mengkontrol imunitas yang diperantarai sel. Seng dapat meningkatkan jumlah sel T- 
effector, T-prekursor, dan aktivitas sel pembentuk antibody. ${ }^{19}$

Kerusakan jaringan host pada penyakit periodontal dapat disebabkan oleh aktivitas neutrofil elastase yang destruktif. Neutrofil elastase merupakan enzim yang paling destruktif di tubuh dengan kemampuan untuk mendegradasi protein matriks ekstraseluler (termasuk kolagen, proteoglikan, fibronektin, reseptor platelet, reseptor komplemen, thrombomodulin, surfactant paru dan cadherins) dan protein plasma (termasuk faktor komplemen, immunoglobulin, beberapa protease dan inhibitor protease). Inhibitor NE adalah $\alpha 1$-antitrypsin. Dalam kondisi fisiologis kadar NE dan inhibitornya seimbang sehingga dapat meregulasi aktivitas NE dengan membentuk "antiprotease screen". 11

Pada keadaan patologis, antiprotease didegradasi oleh oksida-oksida hasil fagositosis bakteri seperti $\mathrm{O}_{2}^{-}, \mathrm{H}_{2} \mathrm{O}_{2}, \mathrm{OH}$ dan $\mathrm{OCl}^{-}$. Oleh karena itu, konsentrasi NE menjadi lebih banyak daripada inhibitornya, sehingga menyebabkan kerusakan jaringan. ${ }^{20}$ Sebagai kofaktor, seng memiliki sifat antioksidan yang menstabilkan struktur membran sel yang berkontribusi pada struktur superoxide dismutase dan menjaga konsentrasi metallothionein jaringan, sehingga seng dapat menetralkan aktivitas destruktif NE yang dipicu oleh oksida-oksida hasil fagositosis. Defisiensi seng dapat mengakibatkan kerusakan jaringan akibat stres oksidatif. ${ }^{21}$

Kesimpulan, konsumsi level seng lebih rendah pada periodontitis ringan daripada gingivitis ringan dan kelompok kontrol sehat. Seng dapat menekan aktivitas destruktif neutrofil elastase. Konsumsi suplemen seng dapat dipertimbangkan sebagai pencegahan dan perawatan penyakit periodontal.

\section{Daftar Pustaka}

1. Mujico JR, Pérez-de-Heredia F, Gómez-Martínez S, Marcos A. In: Mahin K, Malnutrition And Inflammation, Inflammation, Chronic Diseases And Cancer - Cell And Molecular Biology, Immunology And Clinical Bases. InTech 2012: 367-1.

2. Socransky SS, Haffajee AD, Goodson JM, Lindhe J. New concepts of destructive periodontal disease. $\mathbf{J}$ Clin Periodontol 2005;11: 21-32.

3. Nagase H, Visse R, Murphy G. Structure and function of matrix metalloproteinase and TIMP. Cardiovascular Res 2006; 69: 562-70.

4. Lamster IB, Ahlo J. Analysis of gingival crevicular fluid as applied to the diagnosis of oral andsystemic diseases. Ann N Y Acad Sci 2007; 1098: 216-29.

5. Ganowicz E. Salivary diagnostics-diseases of the oral cavity. Dent Med Probl 2011; 48: 421-30.

6. Bostanci N, Ilgenli T, Emingil G, Afacan B, Han B, Töz H, et al. Gingival crevicular fluid levels of
RANKL and OPG in periodontal diseases: implycations of their relative ratio. $\mathrm{J}$ Clin Periodontol 2007; 34: 370-6.

7. Carroll TP, Catherine MG, Cliff T,Noel GM, Shane JO. Interleukin1, neutrophil elastase, and lipopolysaccharide: key proinflammatory stimuli regulating inflammation in cysticfibrosis. Current Respiratory Medicine Reviews 2005; 1(1): 43-67.

8. Nicu EA, Van der Velden U, Everts V, Van Winkelhoff AJ, Roos D, Loos BG. Hyper-reactive PMNs in Fc gamma RIIa $131 \mathrm{H} / \mathrm{H}$ genotype periodontitis patients. J Clin Periodontol 2007; 34: 938-45.

9. Mizuno T, Yau TM, Weisel RD, Kiani CG, Li RK. Elastin stabilizes an infarct and preserves ventricular function. Circulation 2005; 30 (Suppl.9): 181-8.

10. Daamen WF, Verkamp JH, van Hest JCM, Kuppervelt TH. Elastin as Biomaterial for Tissue Enginering. Biomaterials 2007; 28: 4378-98.

11. Matsuse H, Yanagihara K, Mukae H, Tanaka K, Nakazato M, Kohno S. Association Of Plasma Neutrophil Elastase Levels With Other Inflammatory Mediators And Clinical Features In Adult Patients With Moderate And Severe Pneu-monia. Respir Med. 2007; 101(7):1521-8.

12. Roohani N, Richard H, Roya K, Rainer. Zinc and its importance for human health: An integrative review.J Res Med Sci 2013; 18(2): 144-57.

13. Orbak R, Kara C, Ozbek E, Tezel A, Demir T. Effects of zinc deficiency on oral and periodontal diseases in rats. J Periodontol Res 2007; 42(2): 138-43.

14. Prasad AS, Beck FW, Snell DC, Kucuk O. Zinc In Cancer Prevention. Nutr Cancer 2009; 61: 879-87.

15. Winkvist A, Hörnell A, Hallmans G, Lindahl B, Weinehall L, Johansson I. More distinct food intake patterns among women than men in northern Sweden: a population-based survey. Nutrition Journal 2009; 8: 12.

16. Geraghty P, Mark PR, Catherine MG, Rachel MMB, Tiphine P. Neutrophil elastase up-regulate cathepsin B and matrix metalloproteinase expression 2007.e-publicational@RCSI: http ://epubs. rsci. ie/medart/12.

17. Kornman KS. Mapping the pathogenesis of periodontitis: A new look.J Periodontol 2008;79 (Suppl. 8) $1560-8$.

18. Boşca $\mathrm{AB}$, Miclăuş $\mathrm{V}$, Raţiu $\mathrm{C}$, Melincovici C. Matrix Metalloproteinase-8 - a salivary diagnostic biomarker related to soft tissue destruction in chronic periodontitis. Annals Of RSCB 2012; Vol. XVII, Issue 1.

19. Femiano F, Gombos F, Scully C. Recurrent herpes labialis: A pilot study of the efficacy of zinc therapy. Oral Pathol Med 2005; 34: 423-5.

20. Welters ID, Hirsch J, Menzebach A, Hempelmann G, Müller M. Activation of granulocytes and antiproteases in open heart surgery. Anasthesiol Intensivmed Notfallmed Schmerzther 2005; 40(3): 164-72. 
21. Song Y, Leonard SW, Traber MG, Ho E. Zinc deficiency affects dna damage, oxidative stress, antioxidant defenses, and DNA repair in rats. J Nutr 2009;139(9): 1626-31. 